\title{
Interfaces
}

\section{Literature in the expanded field: intermediality at the crossroads of literary theory and comparative literature}

Jan Baetens and Domingo Sánchez-Mesa Martínez

\section{(2) OpenEdition}

Journals

Electronic version

URL: http://journals.openedition.org/interfaces/245

DOI: 10.4000/interfaces. 245

ISSN: 2647-6754

Publisher:

Université de Bourgogne, Université de Paris, College of the Holy Cross

\section{Printed version}

Date of publication: 1 January 2015

Number of pages: 289-304

ISBN: 9780983175247

ISSN: 1164-6225

Electronic reference

Jan Baetens and Domingo Sánchez-Mesa Martínez, "Literature in the expanded field: intermediality at the crossroads of literary theory and comparative literature", Interfaces [Online], 36 | 2015, Online since 01 January 2018, connection on 04 January 2021. URL: http://journals.openedition.org/interfaces/ 245 ; DOI: https://doi.org/10.4000/interfaces.245

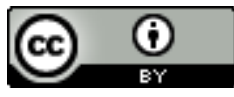

Les contenus de la revue Interfaces sont mis à disposition selon les termes de la Licence Creative Commons Attribution 4.0 International. 


\title{
LITERATURE IN THE EXPANDED FIELD: INTERMEDIALITY AT THE CROSSROADS OF LITERARY THEORY AND COMPARATIVE LITERATURE
}

\author{
Jan Baetens
}

\section{Comparative Literature in the Age of Convergence Culture ${ }^{1}$}

Since the late 1970s, at least, for as always things have already started to happen when one starts noticing them, the traditional field of comparative literature has been characterized by three major shifts. ${ }^{2}$

Firstly, due to a shift in the language profile of both students' choices and program offerings, there has been a radical migration from comparative literature to literary theory. The decreasing interest in the study of foreign languages and, in non-Anglophone areas, the growing hegemony of English have weakened the institutional position of comparative literature, which was strongly challenged by newer disciplines such as theory or cultural studies. ${ }^{3}$

Secondly, the idea of comparative literature as being mainly language-based has become more complex. Not only because language has ceased to be simply verbal in order to become a multi- or polymodal reality, but also, and more importantly, because the very idea of language or text has become subordinated to the idea of medium, an idea that is no longer restricted to verbal or linguistic elements. A significant space within comparative literature focused on interart comparison, a change that offered room for a more medium-based approach to the comparative study of literature. Comparative literature, in other words, is no longer just about textual relationships, it now also integrates elements from nonverbal media. As a dialogical understanding and practice of limits or borders, comparative literature

1 The research of this paper was supported by a grant of BELSPO (Belgian Science Policy agency), in the framework of the Interuniversity Attraction Poles program 07/01 (LMI, Literature and media innovation: http:// lmi.arts.kuleuven.be/).

2 The various reports on the state of the discipline commissioned by the ACLA (Levin 1965; Green 1975; Bernheimer 1993 and Saussy 2004) tracked this evolution and permanent self-questioning.

3 There are some exceptions though. In Spain Comparative Literature, although supported by the Spanish CompLit Association (SELGYC), did not enter the catalogue of academic areas before 2000. After the first ASETEL symposium [http://www.asetel.org], it was institutionally attached to Literary Theory. 
becomes a mode of reading beyond literature, on the basis that literature itself becomes "irreducible" (Guillén 2005, Monegal 2008), that is, impossible to reduce to any other representational or semiotic regime. The creation of word and image programs as well as the institutionalization of this new field through professional organizations such as IAWIS, the International Association of Word and Image Studies ${ }^{4}$ is the logical consequence - and accelerator! — of this evolution, but similar and perhaps more radical observations could be made in the domain of narratology where the leading professional organization, ISSN, The International Association for the Study of Narrative, has explicitly broadened its area of research to all forms of narrative, verbal as well as nonverbal. ${ }^{5}$ The text and, by extension, literature are no longer the center of the comparative universe, whose core is now composed of notions such as medium and adaptation.

Thirdly, the rapid evolution of comparative literature into interart comparison, and eventually into comparative media studies, has taken place precisely when and where literary theory has strongly permeated this shift, ${ }^{6}$ thus becoming the starting point of a terminological battlefield which continues to mobilize large amounts of energy and inventiveness. Terms like intermediality, remediation, hypermediacy, or transmedial, to just quote some of them, have come to the fore in the debates on comparative literature, and it cannot suffice to simply mention that this kind of discussion will be with us for some time to come. A terminological streamlining and simplification is necessary so that other questions can be tackled. In the following paragraphs, we therefore propose some simple distinctions, in the hope that they will help to frame the vital question of literature in the expanded field of today's multimedia or/and transmedial "convergence culture" (Jenkins 2006) more clearly.

\section{A Modest Terminological Proposal}

In order to reduce the terminological debates in the field of comparative studies, we believe it is necessary, as already argued in Sánchez-Mesa (2011), to drastically reduce the existing terminology

4 See: www.iawis.org (IAWIS was created in 1987).

5 See: http://narrative.georgetown.edu/ (The first annual conference of the association took place in 1986).

6 Semiotics and Rhetorics in the case of Group MU, or deconstruction in the case of the pictorial turn coined by WJT Mitchell $(1988,1994)$ 
to a binary opposition, that between intermedial and transmedial. ${ }^{7}$ We are aware of the limitations of such a simplification, but we hope that the practical profits of this move will be more important than its losses. ${ }^{8}$ The question, here, is not to determine whether literature is more or less intermedial or transmedial - we claim that both intermediality and transmediality can be key features of literary form (not necessarily of any literature whatsoever, but of an important part of it) - , but to develop a model as simple as possible to discuss literary issues in the broader contemporary context of digital multimedia culture. In order to enable a correct understanding of transmedia storytelling, we will also introduce two other notions, namely demediation (a concept we borrow from Garrett Stewart 2011) and serialization (and here we will pay tribute to the seminal work of Matthieu Letourneux 2014). However, the twin notions of intermediality and transmediality are essential to our argumentation in this essay.

Medium theory has made it clear that each medium, be it verbal or nonverbal, is by definition plural (Mitchell 2005, Baetens 2014). There are no "pure" media, each medium, including writing, is intermedial and this intermediality is twofold.

On the one hand, each medium is directly or indirectly in contact with other media, and influenced as well as changed by them in the broader mediascape. First Marshall McLuhan (1964) and then Jay David Bolter and Richard Grusin (1999) have insisted on the fact that each medium is actually the result of a remediation due to its conflict with other media. On the other hand, each medium is also itself a blend of several media (in writing, for instance, there is visual signs as well as oral signs, but also

7 That opposition highlighted the difference between those two theoretical modes for describing the transfer between and across traditional mass media cultures and digital interactive cultures. On the one hand, transmedia storytelling, with a dominant cognitive concept of narrative as ontological nucleus of postmodern subjectivity, conveys a perspective that, even when it is rooted in an expanded version of narratalogy (Ryan 2004, 2006) and semiotics (Scolari 2009), finally tends to be oriented to describe the production dynamics of branded content and businesses' opportunities in a convergent culture (Jenkins 2003, 2006, Long 2007, Scolari 2009, Pratten 2011) where that subject basically becomes a proactive consumer of "transmedial fictional worlds" (Saint Gelais 2005; Jenkins 2003; Ryan 2006; Klastrup and Tosca 2004). On the other hand, we found a differential or dialogical theoretical and critical gaze that we called intermedial, more sensitive to friction, anachronisms and conflict at the inter- and intramedial levels, more attentive to the specificities of each media and cultural practice and to their discursive dimension, and consequently, more capable of avoiding the reduction of cultural and artistic experience to abstractness and plain consuming pleasure (Van Looy and Baetens 2003, Sánchez-Mesa, 2011, 2012, Pérez Latorre 2012).

8 There exist of course many other proposals to organize the field. A very famous one, and an equally simple one (although less radically simple than what we hope to achieve here), is the article by Irina Rajewski from 2005. 
tactile and olfactory signs). In practice, however, the use of the term is restricted to these cases in which different types of signs, for instance words and images, are combined. Its influence on transmedial storytelling and narrative theories must be noted, particularly in Ryan/Grishakova (2010) or in the "practice-production oriented" theory of Christy Dena, who speaks of transmodality when two media regimes are concerned: narrative and games (Dena 2009). The more radical stance on intermediality that we defend here tends to claim that even monomodal signs are characterized by internal complexity.

Intermediality, in other words, is not only the general term that defines the relationships between autonomous media, it is also the term that identifies the internal plurality of each medium. The intermedial study of literature therefore does not only refer to the study of the relationships between the literary text and its "others" (for instance the illustrations that accompany it, to give an elementary example), it also includes the study of the literary as a heterogeneous material that conveys a more or less radical "semiotic rupture" within itself (for instance when we interpret aspects of typography, from typeface to page layout and book design, as aspects of the text's visuality - a dimension of literature that has always been at the center of visual and experimental poetry).

As for the other key term, transmediality, we suggest to use it to refer to the fact that more and more works tend to appear in various media. The key word in this depiction of transmediality is "tend to": the reappearance of a work in another medium is a possibility, not a general law; moreover, its presence and impact depend on its historical context. This process is more evident in cyberculture, where a number of factors come together: massive digitizing of cultural texts and global spread of new media languages (Manovich 2001); a strong competition among media entertainment corporations; the proliferation of popular culture reception and distribution platforms and the enhancement of the subjects' creative intervention in the emerging cultural landscape. Various forms of transmediality occur in a context of increased media mobility where all forms of adaptation, recycling and extension are combined. In certain periods, cultures, environments, genres, etc., transmediality will be more present than in others. In principle, however, transmediality is a universal phenomenon. As in the case of intermediality, which is both internal and external, it is necessary here to make a further distinction between two aspects, or even phases, of transmediality.

On the one hand, transmedialization is the mechanism or process that adapts a work that exists in a given medium to another medium. We could call the result of these operations snowball transmedial narrative worlds (as for instance in many Hollywood franchises). This process, as we know, is not one-sided (a book can be adapted into a movie; a movie can be novelized into a book). However, not all adaptations are equal. Once again depending on the context, this or that type of 
adaptation will be more present, from a quantitative as well as from a qualitative point of view. Even if there are as many novelizations as there are filmic adaptations of books, for example, novelizations are definitely less visible, since they are considered culturally less worthwhile than filmic adaptations (Baetens 2008). It should be stressed that transmedialization and adaptation are in no sense synonyms. Even if all transmedializations are adaptations, not all adaptations are transmedializations, since it is perfectly possible to adapt a work while staying within the same medium (the examples of such an internal or intramedial adaptation are countless: translations, reader's digests, rewritings, parodies, etc., are all cases of non-transmedial adaptations), and there are certainly good reasons to maintain a sharp distinction between the broad field of adaptation, which can be seen as part of translation theory, and the narrow field of rewriting (Pérez Bowie 2010).

Yet, on the other hand, there is also the fact that certain works are not first elaborated in a given medium and then adapted into other media, but produced more or less simultaneously in various media, none of them being the "source" of the other ones, by means of a multiplatform production design where a fictional/narrative world emerges through a complex planning of multiple media contributions. This second dimension or moment in transmediality is what Long called "hard transmedia" (2007), defined by Pratten as follows:

Transmedia storytelling' is telling a story across multiple media and preferably, although it doesn't always happen, with a degree of audience participation, interaction or collaboration. In transmedia storytelling, engagement with each successive media heightens the audience's understanding of, enjoyment of and affection for the story. To do this successfully, the embodiment of the story in each media needs to be satisfying in its own right while enjoyment of all the media should be greater than the sum of the parts. $(2011,1)$

From a theoretical point of view, it is crucial to stress the difference between these two types of transmediality, which are at the same time very comparable, since both are aspects of what Jenkins calls "convergence culture" or media collusion, and very different, since the way in which they rely on adaptation goes into different directions. If the former case exemplifies the mechanism of adaptation in a rather traditional sense (a work existing in a certain medium becomes something else in a different medium), the latter, which is of course not sourceless, starts with something that one might call "demediated content." The notion of demediation - a clear reference to Bolter and Grusin's remediation - has been put forward by Garrett Stewart (2011) to identify what he calls bibliobjets, i.e., books used as sculptural material in visual and installation art. Demediation, however, is a concept that goes far beyond its mere use in the contemporary gallery and museum space. Even if the word 
itself does not appear directly in this context, one can find clear echoes of it in discussions on book publishing in the era of digital reproduction. As demonstrated by Thompson (2010), modern multimedia publishers and transmedia storytelling producers have replace "text" by "content" or even "experience." More generally speaking, the idea that there are no bodies or materialities in e-space, only ideas and information (which moreover one wants to be "free," i.e. circulating without being encumbered by material or other obstructions), is one of the strongest myths driving the world of cyberutopia. In the more specialized field of narrative studies, the current success of certain cognitive approaches - those that do not take into account aspects of embodiment, emotions, and situated knowledge and which tend to focus on narrative as story at the expense of narrative as discourse - may have something to do with this dream of pure meaning (Sánchez-Mesa 2014). Our reuse of demediation, which we propose to call demediatization, goes into a different direction, of course. We do not share the mythical idea of content as being immaterial: semiotically speaking, there is no signified without signifier, no substance without form, no interpretant without sign, etc., and N. Katherine Hayles has persuasively driven home the point that the world of bits and bytes is necessarily an embodied culture, which does not dissolve issues of materiality and corporality in empty abstraction and pure idealities (Hayles 1999). We will therefore use the term demediatization here to refer to the fact that the content of a work does not have to be completely actualized in a given medium before it is possible to adapt it into other media; it has been elaborated in such a way that it can be easily elaborated in various media, without it being hindered by the existence of a previously existing form.

The fundamental reason for this demediatization is not the digitization of all media, but the shift from traditional cultural forms to cultural or creative industries, in which the exploitation of a given idea, pilot, or format in as many forms and on as many platforms as possible is an economic necessity. Digitization reinforces this tendency towards demediatization-cum-transmedialization, but it is certainly not the trigger or the fundamental cause of this larger change. Moreover, as convincingly shown by Matthieu Letourneux in his research on serialization in popular culture, demediatization is not just the (partial) putting between brackets of the material form of the initial content, it also involves a far-reaching redefinition of what content actually is or rather which specific form it takes when integrated in the cultural-industrial logic of serialization - it was not included by Jenkins among his seven principles of transmedia storytelling (2009) by chance. To think of a story as content, for instance, does not signify that one tries to invent a story that will resist its adaptation into a movie, a video game, a novel, a comics, a toy, a theme park, etc. as little as possible. It will first of all refer to the shift from story (in the sense of a series of actions organized in the form of a plot) to a story world (i.e., a set of characters and a certain setting). This is made clear in influential articles on transmedial worlds 
theory such as those by Klastrup and Tosca, who define these worlds as: "abstract content systems from which a repertoire of fictional stories and characters can be actualized or derived across a variety of media forms" (409).

Although the notion of transmedia storytelling clearly covers the two aspects of transmediality (traditional adaptation on the one hand, the transmedialization of demediated content on the other hand), the dramatic implications of this distinction for the notion of storytelling are not always acknowledged. In the former case, transmedia storytelling will be closer to story adaptation as it unfolds in traditional franchises (i.e., to the adaptation of a story that has already been embodied and materialized in a narrative discourse, hence the difficulties of adapting it easily or seamlessly into another medium). In the latter, transmedia storytelling will have more to do with adding a storyline to a story world (and here the verbal realization of the story will be less elaborate, in order to avoid problems of medium migration as much as possible).

\section{Literature, a "residual" practice?}

It is time now to return to the "literature" in "comparative literature" and to examine its position, which we believe vital, in the new digital context, which has become the context of all cultural production today (Hayles 2008). The fact that any form of production whatsoever is now impacted and transformed by the digital turn in culture, however, does not imply that literature and the book have become residual domains of culture, whose dominant and emergent forms (to follow here the terminology coined by Raymond Williams 1977) would then be digital and multimedia.

One may have the impression that literature is now evolving towards new forms of transmedia storytelling. True, this is a decisive turn or shift in contemporary writing. However, it would be dangerous to conclude that this evolution is linear or teleological. In this case, there is no reason at all to think that the literature of tomorrow will become transmedia storytelling, with only a marginal place left for what used to be considered literature and its traditional mediations. Even Henry Jenkins made it clear from the beginning that "not all stories will flow across media" (2003), right after pointing to Hollywood's pitches as the referential scenario against which transmedial storytelling's focus on characters and worlds must be understood.

There are two main reasons that support our way of thinking.

First of all, there is the strange observation (at least according to us) that the link between transmedia and storytelling is far from being as natural and self-evident as it seems to have become. 
After all, most innovative literature of the last century has had, sometimes implicitly but most of the times very explicitly, a strong antinarrative bias. ${ }^{9}$ The Anglo-Saxon Modernist novel has been accused of doing away with the very basis of storytelling (Kermode 2000). Other Modernist movements have either ignored the novel (cf. French Surrealism) or tried to eradicate its most fundamental building blocks, such as time, space, character, plot, etc. (as in the French New Novel). It is true that the return of story and plot, after the manifold experiments of the twentieth century, is a general characteristic of contemporary writing, yet this return of the narrative does not at all imply that all literature (and for clarity's sake we will stick here to prose literature) is by definition narrative or that storytelling is, equally by definition, the dominant feature of literature. Even in a narrative the emphasis can be put on other aspects, with the story just being a pretext to work out other priorities (such as style or philosophical reflection). The exclusive emphasis on storytelling is therefore a deplorable shrinking of literature's possibilities, which the accompanying emphasis on demediatization in certain forms of transmedia storytelling of course unfortunately reinforces (as argued above, that kind of storytelling tends to foreground elements of story world rather than storytelling itself, the latter being no more than an expansion of the former). In other words: in order to further explore its possibilities, the worst thing that transmedialized literature can do is continue to focus exclusively on storytelling. In practice, this is of course not what is currently happening, as can be seen very easily in the anthologies composed by ELO (Electronic Literature Organization), for instance, and it is reasonable to foresee that the theoretical study of transmedia literature will open itself to nonnarrative forms of writing.

In line with this first argument, we would also like to recall the dramatic ideological critique of storytelling as a marketing technique, for instance in political campaigns (Salmon 2007). The seducing power of stories is well known by all literary scholars, who have often stressed the capacity of keeping the audience under the charm of the storyteller as one of the most fundamental features of narrative. As all narratologists know, the audience must find an interest in the story that is told, failing which the story will not work, and it is the task of the storyteller to avoid the "so what?" question. Nevertheless, there is always a thin line between raising interest and crude manipulation, and critiques of storytelling as marketing are not dissimilar to critiques of manipulative uses of semiotics, such as for instance the instrumentalization of the language of gestures as a ready-to-use tool for decoding the body language of business partners during face-to-face negotiations (Winkin 2003). To a certain extent, one might wonder whether there is not a profound historical convergence (sic) between the

9 Similar remarks could be made for the field of painting and sculpture, with Greenbergian Modernism aspiring to exclude story and narrative as non-essential to painting (Greenberg himself sometimes uses the word "literature" to define a painting's concern with content matter). 
appropriation of transmedia storytelling by today's cultural industries and the general embrace of the post-medium condition by the multimedia conglomerates in the 1990s (Krauss 1999). In both cases the basic industrial-commercial objective is to promote new forms of (demediatized) content that can only be accessed through the purchase of new (multimedia) equipment.

Second, one has to recognize also that the emergence of digital culture is not only a phenomenon that replaces older, non-digital, forms of writing with newer, digital and multimedia forms of writing, it also produces a mechanism of readaptation - a mechanism that Bolter and Grusin call repurposing: an "old" medium (in this case literature) reacts to a newer one (digital multimedia writing, or why not, transmedia storytelling, as one of its concrete manifestations) by incorporating elements of the new medium or, more radically, to put forward medium-specific elements, i.e., elements that resist transmedialization. ${ }^{10}$ Although this is not a domain that Bolter and Grusin explore, it is precisely what many artists do, in literature as well as in other, nonverbal arts.

In the last part of this essay, we would like to briefly present some examples borrowed from contemporary literary and cultural practices, that suggest the creative reinvention of literary writing in today's digital environment. These examples are borrowed from five fields or subfields, which of course are far from exhaustive but which we hope to be as representative as possible. What interests us here particularly is the width and scope of the domains these examples hint at.

The most blatant examples of literary writing that exceeds storytelling in the shallow sense of the word (namely as narrative continuation of a demediatized story world) can of course be found in poetry. Not only because poetry insists on other dimensions than narrative, which is a truism in Modernist literature, but also because it so strongly opposes the ideas of demediatization and dematerialization. Digital poetry is often extremely medium-specific. It relies on features that are digital born and impossible to transfer directly from screen to page-it is of course always possible to transmediatize a digital-born work to a print medium, but this operation is then no longer a simple transfer, but the production of a totally new work, as can be seen for instance in Tokyo by Eric Sadin, who adapts and rewrites in book form a visual hypertext, After Tokyo. Moreover, cultural critics such as Peter Lunenfeld (2001) have suggested that digital literature has in an apparent paradox brought to the fore elements that had been silenced by print, such as the bodily presence and the voice of the actual author: digital poetry tends to evolve towards poetry performance, with the author being present on stage and establishing a creative dialogue with the software and hardware of his or her digital

10 Medium-specificity, of course, is not the same as purity: contemporary visions of medium-specificity allow for both internal diversity and historical change (Costello 2008). 
creation (this is what he calls the "demo or die" approach, see also Baetens and Van Looy 2008). Additionally, one should stress the intense presence, both qualitatively and quantitatively, of (print) poetry within the digital environment. A good example here is The Cosmonaut (El Cosmonauta), a Spanish SF movie directed by Nicolas Alcalá (2013), ${ }^{11}$ not only notable for its use of crowdfunding and a Creative Commons production license, but also for the role of poetry in its production (the work is partially inspired by a collection by Henry Pierrot, Poetics for Cosmonauts, 2005), its intertext (mainly Tarkovsky), the work itself (the soundtrack contains many poetic elements), and its transmedial companion (The Cosmonaut is nowadays in the center of a transmedial universe from which (print) poetry is far from absent).

A second group of examples has less to do with the integration - and persistence! — of print literature in transmedial environments than with the development of new forms of print production that combine medium-specific aspects of writing and reading in print on the one hand and a keen awareness to develop precisely in print form some of the new questions being addressed by the digital turn. Mark Danielewsky's House of Leaves (2000) or Jonathan Safran Foer's Tree of Codes (2010) are well-known recent examples of a movement that might be called "back to the book" (to quote the title of a research program chaired by Kiene Brillenburg Wurth at Utrecht University), but actually the belief that print culture is not defenceless, so to speak, against the digital turn and that it is even well equipped to explore many still uncharted possibilities is no longer a marginal or reactionary position. ${ }^{12}$ An interesting variation on this "back to the book" principle can be observed in the field of graphic literature, more specifically in the now booming graphic novel field. Despite the myriad of challenging examples and models one can find today in the field of digital comics and graphic novels, it should be stressed that the most innovative creators in the field (one may think here of authors such as Chris Ware, Charles Burns or Daniel Clowes) continue to prefer to work in print rather than looking at the 1001 new possibilities of the digital. And this resistance cannot only be explained by the visual training of most of these artists, all graduates from art schools, and their almost fetishist fascination with paper and ink. No less important is their awareness of the fact that print is better equipped than screen to explore the most distinctive feature of graphic narrative in comics and graphic novel: the combination

11 http://es.cosmonautexperience.com

12 In the Spanish context the tendency known as "afterpop" (following Eloy Fernández Porta's essay of the same title, 2010) or "generación mutante" can be considered from this stance, particularly in the cases of Fernández Mallo (the Nocilla Project, http://blogs.alfaguara.com/fernandezmallo/), Juan F. Ferré (Providence, Karnaval) or Vicente L. Mora (Alba Crom), whose essay El lectoespectador (2012) is referential for the repurposing strategies in twenty-first-century literary writing. 
of sequentiality — one panel after another — and simultaneity — the page as a unified composition —on these issues, see Groensteen (2013), Miodrag (2013) and Chute and Jagoda 2014).

Another category of examples can be found in the context of what was initially called "conceptual writing" (Dworkin and Goldsmith 2011) and now "uncreative" writing (Goldsmith 2011, Perloff 2011). Influenced by a wide range of twentieth-century artistic movements (for instance readymade art, Burrough's cut-up writing, or the Situationist détournement), the creative use of sampling, copying and plagiarizing has been enhanced and accelerated by the emergence of digital tools in literature. Here as well, however, the idea that thanks to the personal computer the writer can now start doing what visual artists could do after the invention of photography (namely creatively reproducing the world instead of copying it in an artisanal form) has not put an end to print culture, on the contrary. A good example here is the remake of Borges' short story cycle El Hacedor (1960) by Agustín Fernandez Mallo, symptomatically subtitled Remake (2011). In his version of El Hacedor, Mallo offers a kind of digitally expanded cover version of the original (more or less in the spirit of a cover version of a song in popular music). Although unmistakably triggered by the cultural Zeitgeist of creative reproduction (and one should not forget that Borges himself was a major and sublime example of this spirit!), Mallo's work would miss much of its sharpness if produced online, for instance as a kind of fan fiction. In that sense, he is very illustrative of the belief of many contemporary writers that it makes sense to continue to work in print.

A fourth cluster where there is room for literature is that of the web documentary, an emerging non-fiction interactive mode which roots itself in the avant-garde cinematic works of Dziga Vertov, Chris Marker or the city symphonies by Jean Vigo or Walter Ruttman and by the new media aesthetics defined by the database according to Lev Manovich. An i-doc like Highrise: Out of my Window (Caterina Cizek, NFB) ${ }^{13}$ expands those urban collage movies into a cybertextual narrative, multiplying the reader-viewer-user virtual voyage around the world (from Johannesburg to Havana; from Chicago to Phnom-Penh) through the testimonies of citizens inhabiting high buildings in top-populated towns. In addition to navigating across the high-rise map (the second fundamental aesthetical principle of new media, Manovich dixit), internauts can upload their own pictures to Flickr, thus allowing for another kind of intervention within this worldview. This shrewd exploration of factual narratives meets a strong immersive emphasis in Thanatorama (by the French multimedia group Upian), ${ }^{14}$ self-defined as "une aventure dont vous êtes le héros mort." Choosing paths along a hypermedia narrative structure, a

13 http://highrise.nfb.ca, winner of the International Digital Emmy for Non-Fiction 2011.

$14 \mathrm{http}: / / w w w . t h a n a t o r a m a . c o m$ 
second person narrator introduces the departed to the various processes taking place once she joins the realm of the deceased (contract of death certificate; burial or cremation), including getting acquainted with professionals of the death (embalmers, funeral home drivers or undertakers, etc.). Writing spaces was the metaphor launched by Jay D. Bolter (1991) when he referred to the centrality of space in new media remediating processes. Pervasive narratives strengthen this trend, exploiting GPS, ARG and the tradition of role play games.

Last but not least, we end our promenade along the passages of digital non-places with precisely the so called e-literature, an heterogeneous ensemble of practices, originally categorized, among others, by N. Katherine Hayles and the ELO, by means of a digitally restricted ontology. As Lev Manovich's last title states, "software takes command," while design, production, distribution, implementation, reception and interaction take place through computer devices. A beautiful specimen of e-literature is delivered by J. R. Carpenter's In absentia (launched in 2008), a critical web project on the gentrification of Montreal. This work is a good example of the ways in which new forms of digital (in this case hypertextual) narrative manage to propose solutions that include writing. ${ }^{15}$ Here is how the author describes the project:

It used short "postcard story" narratives and the Google Maps API to address issues of gentrification and its erasures in the Mile End neighborhood of Montreal. The piece was commissioned by an artist-run-centre based in the neighborhood. There are stories in English and in French, written by multiple authors. The launch party was a neighborhood block party held on the Quebec national holiday - thousands of people attended — an animated version of the piece was projected on the underside of a viaduct throughout the event. Stories were added over the course of the summer and into the autumn of that year. ${ }^{16}$

In absentia nicely illustrates a tendency within e-literature that resists the idea of breaking up the story in many small lexias that the reader has to recompose on his or her own. Instead, one notices a strong propensity toward the increased narrativity of the lexias: each lexia proposes a (fictional) short story in which the author gives voice to the low-income neighbours' fear of eviction. These stories are directly linked with the non-verbal context and open the readers' interpretation: the stories should not only be read as representations of something that has happened, but also as an ongoing

15 See URL http://collection.eliterature.org/2/works/carpenter_in_absentia/ (this work has been included in the second anthology of the Electronic Literature Organization).

16 Personal email to Jan Baetens, Dec. 16th 2011. 
experience whose end is yet to be discovered. Most important, however, is the fact that this fictional web documentary purportedly limits the use of "clicking through:" although the reader is of course invited to visit more than one page or section, the work is built in such a way that its (momentary) interruption does not prevent the reader from understanding the whole. In that sense, it invites readers and co-authors to maintain rather classic forms of narrative, rather than to play with the manifold technological possibilities of the new writing tools.

In our brief overview, the reader will surely miss the mention of some other dominant media or cultural genres that are extremely relevant for the discussion we have raised here. Television series or videogames both pose enormous and stimulating challenges to our theoretical and critical framework. Promising developments are being gained in these domains by Rosendo's readings of the intermedialization (the literary fantastic) and transmedialization in Alan Wake (Remedy Ent.) and the transfictional character in Sherlock (BBC) (Rosendo 2015a, 2015b).

\section{From Narrative to Transmedia Storytelling and Back}

In this paper, we have tried to specify the position of literature in the broader field of transmedial cultural practices built on the double idea of narrative and storytelling. This attempt first of all provided the opportunity to make some terminological proposals that may help clear the terminological substratum of the debates, more specifically concerning three inextricably related notions (intermedial, transmedial, demediation). These terminological specifications emphasize the singular status of the notion of storytelling in what is today considered the default option of any form of narrative in digital multimedia productions: transmedia storytelling. It indeed appears that, on the one hand, the notion of storytelling covers only a (more or less small) part of transmedial narrative, and that, on the other hand, both storytelling and narrative address basic notions such as adaptation and medium in quite different terms. Finally, we have briefly presented some examples of the use, persistence, or even invention of forms of literature and literary narrative within digital environments. These examples as well as the diversity of the domains from which they are borrowed seem to suggest that there is room for renewed forms of literary narrative in the world of transmedia storytelling. 


\section{Works Cited}

BOLTER, Jay David, and Richard GRUSIN. Remediation: Understanding New Media. Cambridge, Mass.: MIT Press, 1999.

BAETENS, Jan. La Novellisation. Du Film au Roman. Brussels : Les Impressions Nouvelles, 2008.

_. "Le médium n'est pas soluble dans les médias de masse." Hermès 70 (2014): 40-45.

BAETENS, Jan, and Jan VAN LOOY. Close Reading New Media: Analyzing Electronic Literature. Leuven: Leuven University Press, 2003.

—. .E-poetry: a cultural analysis." Journal of E-Media Studies 1-1 (2008). http://journals.dartmouth.edu/cgibin/ WebObjects/Journals.woa/2/xmlpage/4/article/28

CARPENTER, J. R. in absentia. 2008. http://collection.eliterature.org/2/works/carpenter_in_absentia/about.html

CHUTE, Hillary, and Patrick JAGODA, eds. Comics \& Media, special issue of Critical Inquiry 40: 3 (Spring 2014).

COSTELLO, Diarmuid. “On the Very Idea of a 'Specific' Medium: Michael Fried and Stanley Cavell on Painting and Photography as Arts." Critical Inquiry, 34:2 (Winter 2008): 274-312.

DANIELEWSKI, Mark Z. House of Leaves. New York: Pantheon, 2000.

DENA, Christy. Transmedia Practice: Theorising the Practice of Expressing a Fictional World across Distinct Media and Environments. Sydney: University of Sydney, School of Letters, Art and Media. (PhD). 2009. $\mathrm{http}: / / \mathrm{www} . c h r i s t y d e n a . c o m / \mathrm{phd} /$

DWORKIN, Craig, and Kenneth GOLDSMITH, eds. Against Expression: An Anthology of Conceptual Writing. Chicago: Northwestern University Press, 2011.

FERNANDEZ MALLO, Agustín. El Hacedor (de Borges). Remake. Madrid: Alfaguara, 2011.

FOER, Jonathan Safran. Tree of Codes. London: Visual Editions, 2010.

GOLDSMITH, Kenneth. Uncreative Writing: Managing Language in a Digital Age. New York: Columbia University Press, 2011.

GROENSTEEN, Thierry. [Bande dessinée et narration]. Comics and Narration. Jackson: The University Press of Mississippi. 2013.

GUILLÉN, Claudio. Entre lo uno y lo diverso. Introducción a la literature comparada (Ayer y hoy). Barcelona, Tusquets, 2005.

GRUSIN, Richard, and Jay D. BOLTER. Remediation: Understanding New Media. Cambridge, Mass.: MIT Press, 1999.

HAYLES, N. Katherine. How We Became Posthuman: Virtual Bodies in Cybernetics, Literature and Informatics. Chicago: Chicago university Press, 1999.

—. Electronic Literature. Notre-Dame: Notre-Dame University Press, 2008.

JENKINS, Henry. "Transmedia storytelling. Moving characters from books to films to video games can make them stronger and more compelling." MIT Technology Review (2003). http://www.technologyreview.com/ biotech/13052/.

—. Convergence Culture: Where Old and New Media Collide. New York: New York University Press, 2006. 
KERMODE, Frank. The Sense of an Ending: Studies in the Theory of Fiction (with a New Epilogue). New York: Oxford University Press, 2000.

KLASTRUP, Lisbeth, and Susana TOSCA. "Transmedial worlds: Rethinking cyberworld design”. Proceedings of the International Conference on Cyberworlds 2004, IEEEE Computer Society. Los Alamitos, CA. (2004).

http://www.itu.dk/people/klastrup/klastruptosca_transworlds.pdf

KRAUSS, Rosalind. "A Voyage on the North Sea": Art in the Age of the Post-Medium Condition. London: Thames and Hudson, 1999.

LETOURNEUX, Matthieu. Penser la sérialité: supports, genres, culture médiatique. HDR Paris Ouest La Défense (6 Dec. 2014). Unpublished.

LONG, Geoffrey. Transmedia Storytelling: Business, Aesthetics and Production at the Jim Henson Company. PhD Diss. MIT (Cambridge, Mass.), 2007.

LUNENFELD, Peter. Snap To Grid. Cambridge, Mass.: MIT Press, 2001.

MANOVICH, Lev. The Languages of New Media. 2000. Cambridge, Mass.: MIT Press, 2001.

MCLUHAN, Marshall. Understanding Media. New York: McGraw Hill, 1964.

MIODRAG, Hannah. Comics and Language. Jackson: The University Press of Mississippi, 2013.

MITCHELL, W. J. T. “There Are No Visual Media.” Journal of Visual Culture 4: 2 (2005): 257-266.

MONEGAL, Antonio. "La literatura irreductible". Ínsula : revista de lettras y ciencias humanas 733-734 (2008): 2-5.

PÉREZ BOWIE, José Antonio. Reescrituras filmicas: Nuevos territorios de la adaptación. Salamanca : Ediciones Universidad Salamanca, 2010.

PÉREZ LATORRE, Oliver. El lenguaje videolúdico. Análisis de la significación del videojuego. Barcelona, Laertes, 2012.

PERLOFF, Marjorie. Unoriginal Genius. Chicago: Chicago University Press, 2011.

PIERROT, Henry. Poetics for Cosmonauts. León: Ediciones Leteo, 2005.

PRATTEN, Robert. Getting Started in Transmedia Storytelling: A Practical Guide to Beginners. Scotts Valley: CreateSpace Amazon, 2011.

RAJEWSKY, Irina O. "Intermediality, Intertextuality, and Remediation: A Literary Perspective on Intermediality." Intermédialités/Intermedialities 6 (2005): 43-64.

ROSENDO, Nieves. "Lo fantástico en Alan Wake: remediación, intermedialidad, transmedialidad". Brumal. Revista de investigación sobre lo Fantástico 3: 1 (2015a, forthcoming).

—. "Adaptación, transmedialidad, transficcionalidad: Sherlock o una aproximación a los personajes transmediales". 2015b. 2nd Congreso Internacional ASETEL, (CSIC, Madrid, 28-30 Apr. 2015b) Unpublished.

RYAN, Marie-Laure, ed. Narrative Across Media: The Languages of Storytelling. Lincoln-London: University of Nebraska Press, 2004.

RYAN, Marie-Laure. Avatars of Story. Minneapolis: University of Minnesota Press, 2006.

RYAN, Marie-Laure, and Marina GRISHAKOVA, eds. Intermediality and Storytelling. Berlin: Walter de Gruyter, 2010.

SADIN, Eric. Tokyo. Paris: P.O.L., 2005. 
304

Interfaces $36(2014-2015)$

SAINT-GELAIS, Richard. "Transfictionality." The Routledge Encyclopedia of Narrative Theory. Eds. David Herman et al. London: Rutledge, 2005. 612-13.

SALMON, Christian. Storytelling. La machine à fabriquer does histoires et à formater les sprits. Paris : La Découverte, 2007.

SÁNCHEZ-MESA, Domingo. "Literatura aumentada. Intermedialidad / Transmedialidad o el Viaje de Alicia a través de las pantallas". Literatura e Internet. Nuevos Texts, Nuevos Lectores. Ed. Salvador Montesa. Málaga, Publicaciones del Congress de Literatura Española Contemporánea, 2011. 109-129.

—. "Videojuegos y Cine: intermedialidad / transmedialidad". Teoría y práctica de la adaptacion filmica. Ed. Barbara Zecchi. Madrid, Editorial de la Universidad Complutense, 2012. 205-235.

—. "Transmedia Storytelling: Is it the End of Discourse Theory?", Granada, 1st International Seminar on Transmedial Narratives (Granada, 26-28 March 2014). Unpublished.

SCOLARI, Carlos A. "Transmedia Storytelling: Implicit Consumers, Narrative Worlds and Branding in Contemporary Media Production ." International Journal of Communication 3 (2009): 586-606.

STEWART, Garrett. Bookwork: Medium to Object to Concept to Art. Chicago: Chicago University Press, 2011. THOMPSON, John B. Merchants of Culture. London: Polity, 2010.

YÁÑEZ, María, "Informe: documental interactive. Con la realidad sí se puede jugar". 2011. EMBED. At Audiovisual integrado. http://antes.embed.at/article43.html.

WILLIAMS, Raymond. Marxism and Literature. Oxford and New York: Oxford University Press, 1977.

WINKIN, Yves. La communication nest pas un marchandise. Brussels : Labor, 2003. 